\title{
Pengaruh Variasi Temperatur Quenching dan Media Pendingin terhadap Tingkat Kekerasan Baja AISI 1045
}

\author{
Gunawan Dwi Haryadi ${ }^{1}$, Angelius Fredy Utomo², I Made Wicaksana Ekaputra ${ }^{2 *}$ \\ ${ }^{1}$ Teknik Mesin, Universitas Diponegoro \\ Jl. Prof. Sudharto, SH., Tembalang-Semarang 50275 \\ ${ }^{2}$ Teknik Mesin, Universitas Sanata Dharma \\ Kampus III, Paingan, Maguwoharjo, Sleman Yogyakarta 55281 \\ *E-mail: made@usd.ac.id
}

Diterima: 27-05-2021; Direvisi: 26-07-2021; Dipublikasi: 27-08-2021

\begin{abstract}
Abstrak
Baja AISI 1045 merupakan baja yang memiliki kadar karbon sebesar 0,45\%. Baja jenis ini banyak digunakan pada komponen kendaraan sepeda motor seperti: roda gigi, poros, dan bantalan. Pada penerapannya, baja sering mengalami keausan akibat dari gesekan dan tekanan. Untuk menjaga agar umur baja lebih tahan lama terhadap gesekan maka perlu dilakukan perlakuan panas quenching. Perlakuan panas quenching ini sangat berperan penting dalam upaya meningkatkan sifat mekanik yang terdapat pada baja AISI 1045. Perlakuan panas quenching yang digunakan pada penelitian ini yaitu $800^{\circ} \mathrm{C}, 850^{\circ} \mathrm{C}$, dan $900^{\circ} \mathrm{C}$ holding time selama 25 menit dengan menggunakan media pendingin air dan oli SAE 20W-50. Hasil beberapa data pengujian selanjutnya diolah dan dibandingkan tingkat kekerasan pada setiap variasi temperatur. Data yang diperoleh dari pengujian kekerasan Vickers $(H V)$ sangat bervariasi. Pada baja AISI 1045 tanpa perlakuan (raw material) didapat nilai rata-rata kekerasan sebesar 202,78 $\mathrm{HV}$. Selanjutnya nilai rata-rata kekerasan dengan media pendingin air pada temperatur $800^{\circ} \mathrm{C}$ sebesar $398,48 \mathrm{HV}, 850^{\circ} \mathrm{C}$ sebesar $457,02 \mathrm{HV}$, dan $900^{\circ} \mathrm{C}$ sebesar $496,42 \mathrm{HV}$. Berikutnya, nilai rata-rata kekerasan dengan media pendingin oli SAE $20 \mathrm{~W}-50$ pada temperatur $800^{\circ} \mathrm{C}$ sebesar $252,87 \mathrm{HV}, 850^{\circ} \mathrm{C}$ sebesar $402,55 H V$, dan $900^{\circ} \mathrm{C}$ sebesar $476,92 \mathrm{HV}$. Nilai kekerasan optimal pada baja AISI 1045 terdapat pada suhu $900^{\circ} \mathrm{C}$ dengan media pendingin jenis air sedangkan nilai kekerasan paling rendah terdapat pada baja tanpa perlakuan (raw material).
\end{abstract}

Kata kunci: Baja AISI 1045; kekerasan; media pendingin; quenching; temperatur

\begin{abstract}
AISI 1045 is widely used in motorcycle components such as: gears, axles, and bearings. During its application, the components experiences wear as a result of friction and pressure. The quenching method may be chosen for improving its mechanical properties. In this study, the AISI 1045 was investigated namely $800^{\circ} \mathrm{C}, 850^{\circ} \mathrm{C}$, and $900^{\circ} \mathrm{C}$ holding time for 25 minutes using water and oil cooling media SAE 20W-50. Then, the results of the test data are processed and compared the level of hardness at each temperature variation. The data obtained from the Vickers hardness test (HV) varies widely. In AISI 1045 steel without treatment (raw material), the average value of hardness is 202,78 HV. Then, the average value of hardness with water cooling media at a temperature of $800^{\circ} \mathrm{C}$ is $398,48 \mathrm{HV}, 850^{\circ} \mathrm{C}$ is $457,02 \mathrm{HV}$, and $900^{\circ} \mathrm{C}$ is $496,42 \mathrm{HV}$. Then, the average value of hardness with oil cooling media SAE $20 \mathrm{~W}$-50 at a temperature of $800^{\circ} \mathrm{C}$ is $252,87 \mathrm{HV}, 850^{\circ} \mathrm{C}$ is $402,55 \mathrm{HV}$, and $900^{\circ} \mathrm{C}$ is $476,92 \mathrm{HV}$. The optimal hardness value on AISI 1045 steel is at a temperature of $900^{\circ} \mathrm{C}$ with water-type cooling media, while the lowest hardness value is in steel without treatment (raw material).
\end{abstract}

Keywords: AISI 1045 steel; cooling media; hardness; quenching; temperature

\section{Pendahuluan}

Baja AISI 1045 adalah baja karbon yang memiliki komposisi kandungan 0,42-0,50\% C, 0,50-0,80\% Mn, 0,035\% S, 0,17-0,37\% Si, 0,25\% Ni, 0,25\% Cr, 0,035\% P dan termasuk golongan baja karbon menengah (medium carbon steel) [1]. Baja karbon menengah jenis ini banyak digunakan sebagai komponen automotif misalnya untuk pembuatan roda gigi, poros, dan bantalan pada kendaraan bermotor [2]. Baja AISI 1045 sering disebut sebagai baja karbon dikarenakan sesuai dengan pengkodean internasional, yaitu seri 10xx berdasarkan nomenklatur yang dikeluarkan oleh AISI dan SAE (Society 
of Automotive Engineers) pada angka 10 pertama merupakan kode yang menunjukan plain carbon, selanjutnya pada kode xx setelah angka 10 menunjukan komposisi kadar karbon pada baja AISI 1045 [2].

Pada penerapannya, baja tersebut harus memiliki sifat ketahanan aus yang baik dikarenakan sesuai dengan fungsinya harus mampu menahan keausan akibat dari gesekan dan beban tekanan [2-3]. Ketahanan aus dapat didefinisikan sebagai ketahanan suatu material terhadap pengurangan dimensi akibat dari suatu gesekan antara permukaan tertentu [2-3]. Salah satu usaha agar umur baja lebih tahan lama terhadap gesekan atau tekanan adalah melalui proses perlakuan panas (heat treatment).

Quenching adalah salah satu proses perlakukan panas melalui proses pendinginan cepat. Pada baja, proses quenching mengakibatnya adanya percepatan pendinginan dari temperatur austenisasi menjadi fase bainite dan/atau martensite untuk mencapai tingkat kekuatan dan kekerasan tertentu [2-4]. Proses quenching dapat menyebabkan nilai kekerasan menjadi meningkat seiring bertambahnya jumlah martensite [4]. Pada komponen sepeda motor yang menggunakan baja AISI 1045 proses perlakuan quenching menjadi salah satu cara yang dapat diterapkan untuk meningkatkan ketahanan aus dan kekerasan secara sederhana. Namun, nilai yang optimum perlu dilakukan berdasarkan parameter proses perlakuan panas yang tepat.

Pada penelitian ini, pengaruh variasi temperatur quenching dan media pendingin pada baja AISI 1045 diinvestigasi. Pengujian kekerasan Vickers dilakukan untuk mengetahui perubahan nilai kekerasan yang terjadi pada paduan baja tersebut. Proses quenching diawali dengan memanaskan baja pada suhu austenite, yaitu $800^{\circ} \mathrm{C}, 850^{\circ} \mathrm{C}, 900^{\circ} \mathrm{C}$ kemudian ditahan selama 25 menit, selanjutnya didinginkan dengan menggunakan media pendingin jenis air dan oli SAE 20W-50.

\section{Metode Penelitian}

\subsection{Pengujian Kekerasan}

Komposisi kimia untuk baja AISI 1045 disajikan pada Tabel 1. Pengujian kekerasan yang dilakukan adalah uji kekerasan Vickers dengan model DHV-50D. Alat ini dilengkapi dengan sistem program, digital, dan mikroskop metallurgy. Pada pengujian menggunakan beban penekanan sebesar $10 \mathrm{~kg}$, waktu penekanan 10 (s). Spesimen yang digunakan berbentuk silinder berjumlah tujuh buah. Dimensi spesimen uji kekerasan Vickers dapat dilihat pada Gambar 1. Alat uji kekerasan Vickers dan lekukan kekerasan Vickers dapat dilihat pada Gambar 2. Perhitungan hasil pengujian Vickers dapat menggunakan persamaan 1.

\subsection{Pengamatan Struktur Mikro}

Pengamatan struktur mikro dilakukan menggunakan optical microscopy dengan lensa okuler objektif M40x0,45 dengan total pembesaran 222x. Pengamatan struktur mikro diawali dengan perlakuan pengamplasan dari kasar ke halus untuk meratakan permukaan (360 $\mu \mathrm{m}, 660 \mu \mathrm{m}, 860 \mu \mathrm{m}, 1000 \mu \mathrm{m}, 1200 \mu \mathrm{m}$, dan $1500 \mu \mathrm{m})$. Selanjutnya menggosokan permukaan spesimen yang telah rata dan halus pada kain majun dan diolesi dengan autosol hingga mengkilat. Kemudian, permukaan spesimen dicelupkan kedalam gelas ukur yang berisi larutan etsa yaitu $\mathrm{HNO}_{3}$ 100\% dan Alkohol 70\% selama 60 detik untuk melihat proses terjadinya korosi pada permukaan baja AISI 1045. Tahap selanjutnya, membersihkan spesimen dengan air kran yang mengalir dan di olesi autosol. Pengamatan struktur mikro dilakukan pada permukaan yang telah diratakan dan dibersihkan spesimen uji kekerasan Vickers. 
Tabel 1. Komposisi baja AISI 1045 (wt\%) menurut [1].

\begin{tabular}{c|c|c|c|c|c|c}
\hline $\boldsymbol{C}$ & $\boldsymbol{M n}$ & $\boldsymbol{S}$ & $\boldsymbol{S i}$ & $\boldsymbol{N i}$ & $\boldsymbol{C r}$ & $\boldsymbol{P}$ \\
\hline $0,42-0,50$ & $0,50-0,80$ & 0,035 maks. & $0,17-0,37$ & 0,25 maks. & 0,25 maks. & 0,035 maks. \\
\hline
\end{tabular}

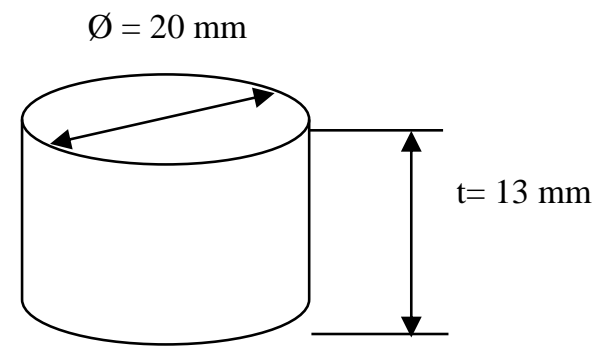

Gambar 1. Dimensi spesimen uji kekerasan Vickers

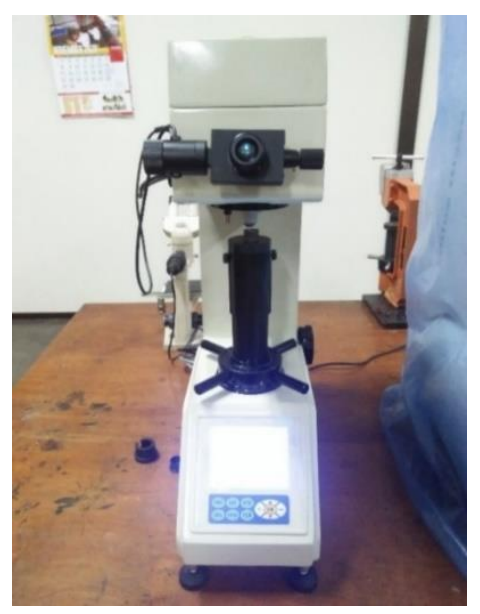

(a)
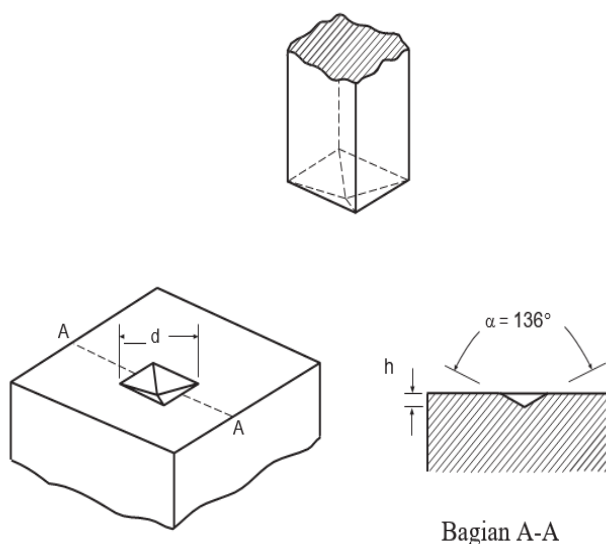

Bagian A-A

(b)

Gambar 2. (a) Alat uji kekerasan Vickers, (b) lekukan kekerasan Vickers [5]

Untuk menghitung nilai kekerasan Vickers dapat menggunakan rumus sebagai berikut [5] :

$H V=\frac{2 \mathrm{P}}{\mathrm{d} 2} x \sin a / 2$

dimana P adalah beban penekanan (kg) dan d adalah Diagonal 1 dan diagonal 2 (millimeter).

\section{Hasil dan pembahasan}

Pada pengujian kekerasan Vickers ini menggunakan material jenis baja AISI 1045. Jumlah penekanan yang dilakukan sebanyak 15 kali. Hasil yang diperoleh dari pengujian kekerasan ini sangat bervariasi nilai kekerasannya, baik untuk baja tanpa perlakuan atau baja setelah mengalami proses perlakuan panas quenching. Perbedaan nilai kekerasan ini diakibatkan adanya sifat kemampukerasan yang berbeda-beda pada material baja. Untuk nilai standar deviasi yang diperoleh pada baja tanpa perlakuan sebesar 11,25. Setelah baja melewati proses perlakuan panas quenching pada suhu $800,850,900^{\circ} \mathrm{C}$ holding time selama 25 menit dengan media pendingin air didapat nilai standar deviasi sebesar 44,82, 31,17, dan 27,80. Selanjutnya, untuk baja AISI 1045 setelah melewati proses perlakuan panas quenching pada suhu 800, $850,900^{\circ} \mathrm{C}$ holding time selama 25 menit dengan media pendingin oli dengan seri SAE 20W-50 didapat nilai standar 
deviasi sebesar 24,93, 19,33, dan 30,58. Pada pengujian kekerasan ini, nilai rata-rata kekerasan Vickers (HV) yang didapat untuk baja tanpa perlakuan sebesar 202,78 HV , selanjutnya untuk baja yang telah dilakukan proses quenching pada suhu $800,850,900^{\circ} \mathrm{C}$ holding time selama 25 menit dengan media pendingin air didapat nilai kekerasan 398,48 HV, 457,02 $H V$, dan $496,42 H V$. Sedangkan, untuk baja yang telah dilakukan proses quenching pada suhu $800,850,900^{\circ} \mathrm{C}$ holding time selama 25 menit dengan media pendingin oli dengan seri SAE 20W-50 didapat nilai kekerasan 251,87 HV, 402,55 $H V$, dan 476,92 HV. Spesimen benda uji yang telah dilakukan proses quenching dengan variasi suhu dan media pendingin akan meningkatkan sifat mekanik dari material tersebut. Pada penerapannya, jika baja AISI 1045 setelah dilakukannya proses quenching ini akan meningkatkan ketahanan aus yang baik sehingga menimalisir terjadinya gesekan (kerusakan) pada komponen sepeda motor seperti: roda gigi, poros, dan bantalan.

\subsection{Pengujian Kekerasan}

Perbandingan nilai kekerasan baja AISI 1045 dengan variasi temperatur quenching dan media pendingin ditampilkan pada tabel 2 serta pada Gambar 3. Pada uji kekerasan ini menggunakan beban penekanan sebesar $10 \mathrm{~kg}$ dengan waktu penekanan selama 10 (s). Pemilihan beban dan waktu penekanan dalam hal ini harus disesuaikan dengan sifat mekanik yang terdapat pada baja AISI 1045. Selanjutnya, setelah dilakukannya proses pengujian kekerasan didapat nilai kekerasan yang bervariasi dimana nilai kekerasan tersebut didapat dari hasil proses quenching dengan tiga variasi temperatur dan media pendingin yang berbeda-beda.

Tabel 2. Hasil pengujian nilai rata-rata kekerasan Vickers berdasarkan variasi temperatur quenching dan media pendingin.

\begin{tabular}{ccc}
\hline No & Baja AISI 1045 & Nilai rata-rata kekerasan Vickers $(\boldsymbol{H V})$ \\
\hline 1 & Tanpa Perlakuan & 202,78 \\
2 & Temperatur: $800^{\circ}$ C Air & 398,48 \\
3 & Temperatur: $850^{\circ}$ C Air & 457,02 \\
4 & Temperatur: $900^{\circ}$ C Air & 496,42 \\
5 & Temperatur: $800^{\circ}$ C Oli SAE 20W-50 & 251,87 \\
6 & Temperatur: $850^{\circ}$ C Oli SAE 20W-50 & 402,55 \\
7 & Temperatur: $900^{\circ}$ C Oli SAE 20W-50 & 476,92 \\
\hline
\end{tabular}

Baja AISI 1045 dengan komposisi kadar karbon sebesar 0,45\% ini memiliki sifat mekanik yang seimbang, dimana sebelum dilakukannya proses quenching hanya mendapatkan nilai kekerasan sebesar 202,78 HV hal ini dipengaruhi dari komposisi yang terdapat pada baja AISI 1045. Komposisi tersebut akan mempengaruhi sifat mekanik dari baja terutama sifat kekuatan dan kekerasan. Selanjutnya, setelah material baja dilakukan proses quenching dengan tiga variasi suhu 800, 850 , dan $900^{\circ} \mathrm{C}$ pada holding time selama 25 menit menggunakan media pendingin air dengan volume 65 liter menjelaskan bahwa terjadi tingkat kenaikan nilai kekerasan yang sangat signifikan, hal ini disebabkan oleh adanya perubahan fase austenite menjadi martensite. Penambahan temperatur dalam hal ini dapat meningkatkan kekerasan pada baja, hal ini dapat dibuktikan pada saat baja dipanaskan hingga mencapai suhu austenite akan mengakibatkan meningkatnya kelarutan karbon sehingga karbon akan terlarut dan menyusup pada saat mencapai suhu austenisasi. Selain itu, pada kondisi baja telah melewati temperatur eutectoid sekitar suhu $723^{\circ} \mathrm{C}$ dan di holding time selama 25 menit maka terjadi peningkatan kelarutan karbon yang mengakibatkan nilai kekerasan pada baja AISI 1045 akan menjadi naik. Struktur kristal yang awalnya FCC (Face Centered Cubic) menjadi BCT (Body Centered Tetragonal) ketika didinginkan secara cepat (non-equilibrium) [6]. Struktur kristal BCT (Body Centered Tetragonal) pada paduan baja akan 
mengakibatkan tingkat kekerasan baja meningkat [6]. Pada temperatur $800^{\circ} \mathrm{C}$ didapat nilai rata-rata kekerasan sebesar $398,48 \mathrm{HV}$, selanjutnya temperatur $850^{\circ} \mathrm{C}$ didapat nilai rata-rata kekerasan sebesar $457,02 \mathrm{HV}$, dan temperatur $900^{\circ} \mathrm{C}$ didapat nilai rata-rata kekerasan sebesar 496,42 $H V$ dengan media pendingin air sebanyak 65 liter.

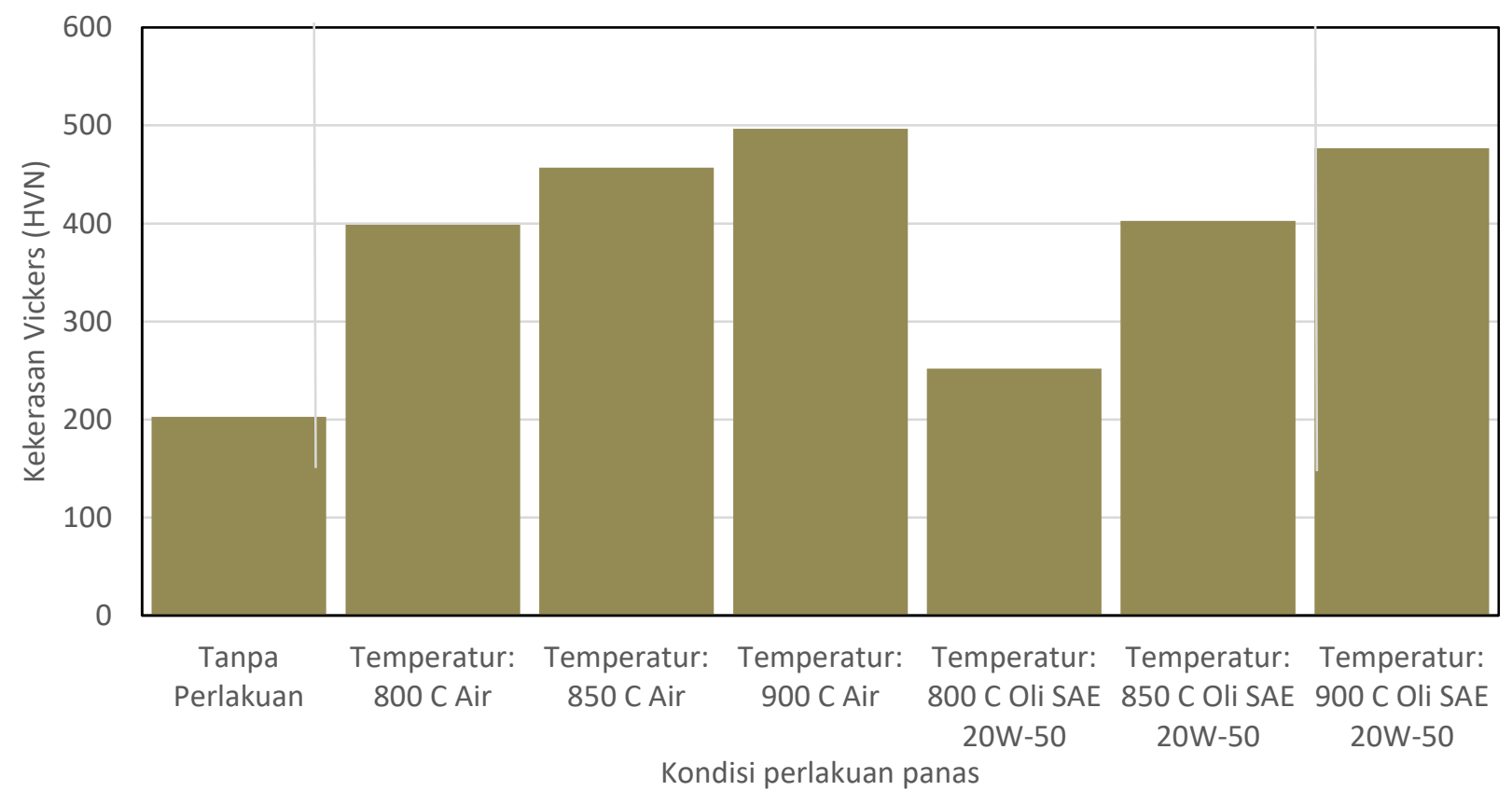

Gambar 3. Grafik perbandingan tingkat kekerasan baja AISI 1045 pada variasi temperatur quenching dan media pendingin

Selanjutnya, untuk hasil pengujian kekerasan dengan menggunakan media pendingin oli dengan seri SAE 20W-50 pada temperatur $800^{\circ} \mathrm{C}$ didapat nilai rata-rata kekerasan sebesar $251,87 \mathrm{HV}$, temperatur $850^{\circ} \mathrm{C}$ nilai rata-rata yang didapat sebesar $402,55 H V$, dan pada temperatur $900^{\circ} \mathrm{C}$ nilai rata-rata yang didapat sebesar 476,92 $\mathrm{HV}$. Dari data hasil nilai ratarata uji kekerasan Vickers menjelaskan bahwa tingkat kenaikan kekerasan paling optimal terdapat baja AISI 1045 dengan perlakuan panas quenching pada suhu $900^{\circ} \mathrm{C}$ media pendingin air sedangkan untuk nilai kekerasan terendah terdapat pada baja tanpa perlakuan. Media pendingin air dan oli memiliki viskositas dan densitas yang berbeda-beda. Pada media pendingin air memiliki nilai densitas sebesar $998 \mathrm{~kg} / \mathrm{m}^{3}$ dan viskositas 1,01 Pa.s. Sedangkan, untuk media oli memiliki nilai densitas sebesar $981 \mathrm{~kg} / \mathrm{m}^{3}$ dan viskositas 4,01 Pa.s [7]. Pada media oli memiliki nilai derajat kekentalan yang berpengaruh pada Severity of Quench [8]. Semakin tinggi nilai densitas maka mengakibatkan laju pendinginan menjadi cepat hal ini akan mempengaruhi tingkat kekerasan baja menjadi naik, sedangkan apabila nilai viskositas dari suatu media pendingin semakin tinggi maka menyebabkan laju pendinginan menjadi sedang hal ini akan mempengaruhi tingkat kekerasan pada baja AISI 1045. Laju pendinginan yang berbeda-beda ini akan mempengaruhi nilai kekerasan dari material baja AISI 1045. Sifat-sifat dari baja setelah mengalami proses pengerasan (quenching) meliputi dari sifat kekuatan, kekerasan, dan ketangguhan pada baja AISI 1045 [9]. Pada saat baja mengalami waktu tahan yang terlalu lama akan mengakibatkan nilai kekerasannya menjadi naik. Selain itu, proses pemanasan di atas suhu kritis dan kemudian diikuti pendinginan cepat dapat meningkatkan kekerasan dari baja [10]. Baja AISI 1045 yang telah mengalami peningkatan nilai kekerasannya dipengaruhi oleh proses perlakuan panas (heat treatment) dan media pendingin yang digunakan [11]. Menurut Kim dan Kwon menegaskan bahwa pada saat proses perlakuan panas, pengaruh suhu dan 
Gunawan Dwi Haryadi dkk /Jurnal Rekayasa Mesin p-ISSN: 1411-6863, e-ISSN: 2540-7678 Vol.16|No.1|255-264|Agustus|2021

komposisi baja terhadap elemen paduan seperti $\mathrm{Ti}, \mathrm{Mo}, \mathrm{Ni}$, dll akan mempengaruhi sifat kekerasan dimana fase austenite berubah menjadi martensite, hal ini disebabkan oleh waktu yang sangat singkat selama proses pendinginan berlangsung. Kim dan Kwon membuktikan pada penelitiannya yang berjudul "Phase Transformation In Machining Steel" pada saat transformasi fase dari pearlite menjadi austenite terjadi pada antar muka yang dikarenakan oleh suhu permukaan meningkat melebihi suhu austenisasi [12].

\subsection{Pengamatan Struktur Mikro}

Struktur mikro baja AISI 1045 baik sebelum dan sesudah dilakukan proses quenching ini menunjukkan perbedaan. Berdasarkan gambar struktur mikro baja AISI 1045 yang terdapat pada Gambar 4(a) dan (b) menjelaskan bahwa pada baja tanpa perlakuan (raw material) yang terdapat dua struktur yaitu ferrite dan pearlite. Ferrite dan pearlite sangat mendominasi pada permukaan baja sehingga menyebabkan sifat ulet, kuat, dan lumayan keras. Pada Gambar 4(a) warna area yang berwarna hitam merupakan pearlite dan warna area yang berwarna putih merupakan ferrite. Gambar 4(b) menegaskan bahwa pada baja AISI 1045 memiliki struktur mikro ferrite dan pearlite. Area yang berwarna putih adalah ferrite sedangkan area yang berwarna hitam merupakan pearlite [13]. Struktur mikro ferrite dan pearlite pada baja tanpa perlakuan ini memiliki nilai kekerasan sebesar 202,78 HV. Ferrite memiliki sifat sangat ulet dan lunak [14].

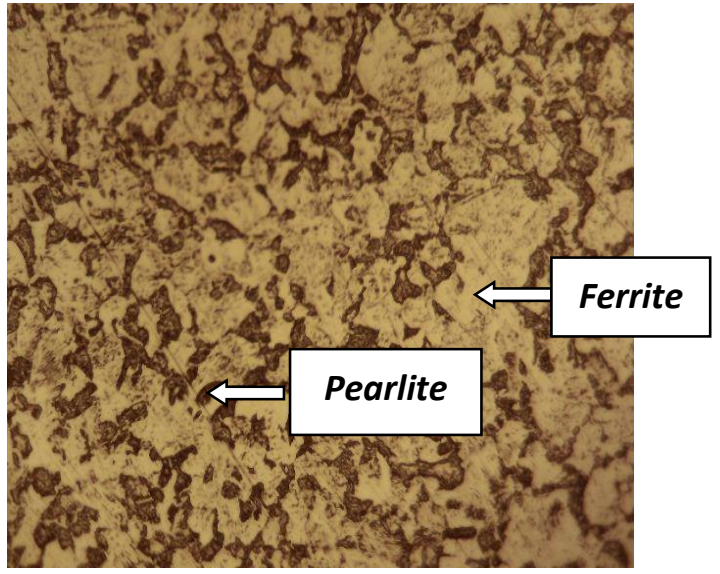

(a)

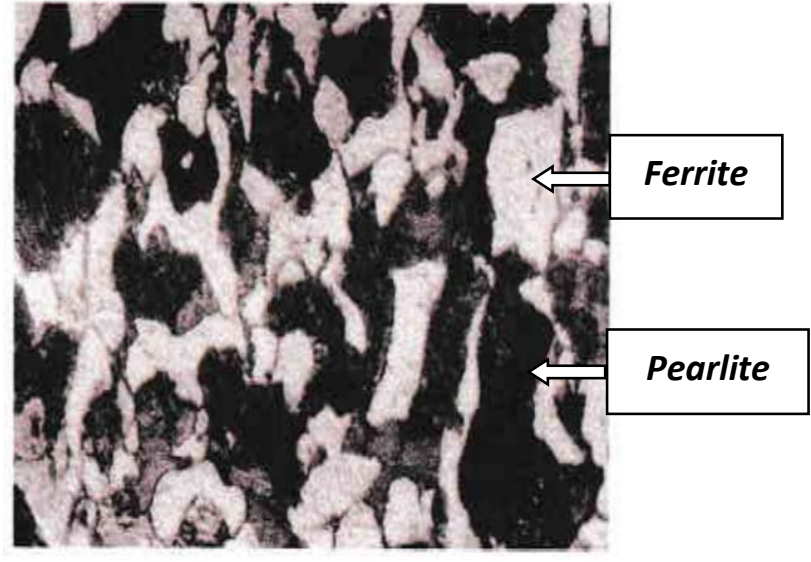

(b)

Gambar 4. (a). Struktur mikro baja AISI 1045 sebelum dilakukan proses heat treatment dengan pembesaran 222x, (b) Foto struktur mikro baja AISI 1045 sebelum dilakukan proses heat treatment de ngan pembesaran 800x, Nital 2\% [13].

Selanjutnya untuk gambar struktur mikro pada temperatur 800,850 , dan $900{ }^{\circ} \mathrm{C}$ dengan media pendingin air didapat struktur martensite yang berbeda-beda dalam hal ini dipengaruhi dari nilai kekerasan yang diperoleh. Struktur mikro pada Gambar 5 dan 6(a) memiliki jumlah martensite yang banyak, dimana dipengaruhi dari nilai densitas air dan laju pendinginan secara cepat. Hasil ini berbeda dengan media pendingin oli SAE $20 \mathrm{~W}-50$ dimana pada temperatur $800^{\circ} \mathrm{C}$ menghasilkan struktur bainite dan martensite yang berbeda-beda. Struktur mikro yang terdapat pada Gambar 6(b) ini memiliki bainite yang banyak. Keberadaan bainite mempengaruhi dari nilai rata-rata kekerasan yang diperoleh sebesar 251,87 HV. Pada pembesaran 222x ini struktur bainite lebih mendominasi dibandingkan struktur martensite. Totten menegaskan bahwa, pertumbuhan bainite ini dikarenakan hasil dari produk dari pertumbuhan ferrite dan cementite 
Gunawan Dwi Haryadi dkk /Jurnal Rekayasa Mesin p-ISSN: 1411-6863, e-ISSN: 2540-7678 Vol.16|No.1|255-264|Agustus|2021

menjadi austenite selama proses dekomposisi eutectoid dengan hal ini cementite yang muncul dalam bentuk non lamelar. Pada kinematika transformasi ini saling berkaitan dengan laju pergerakan difusi karbon pada baja [15].

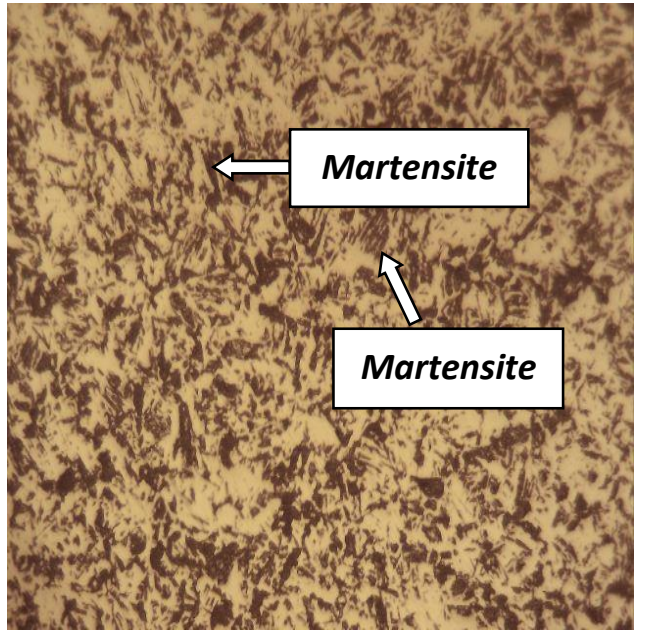

(a)

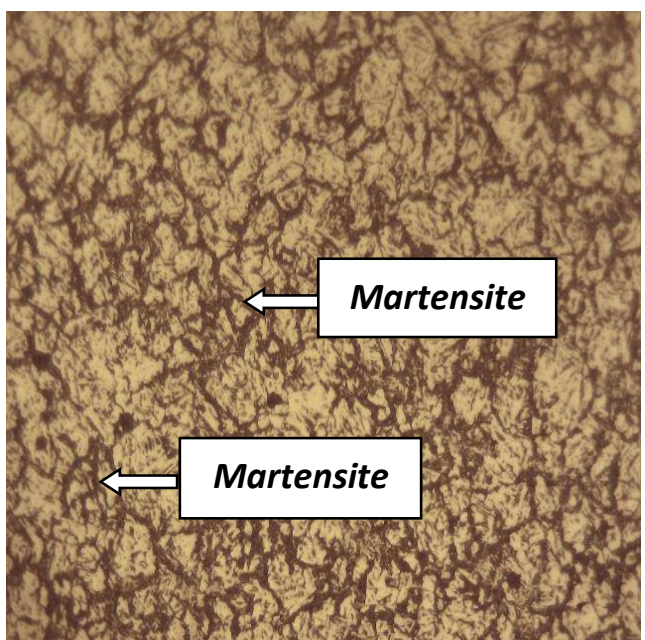

(b)

Gambar 5. (a) Struktur mikro baja AISI 1045 setelah dilakukan proses quenching pada suhu $800^{\circ} \mathrm{C}$ dengan holding time selama 25 menit menggunakan media pendingin air, pembesaran 222x, (b) Struktur mikro baja AISI 1045 setelah dilakukan proses quenching pada suhu $850^{\circ} \mathrm{C}$ dengan holding time selama 25 menit menggunakan media pendingin air, pembesaran 222x.

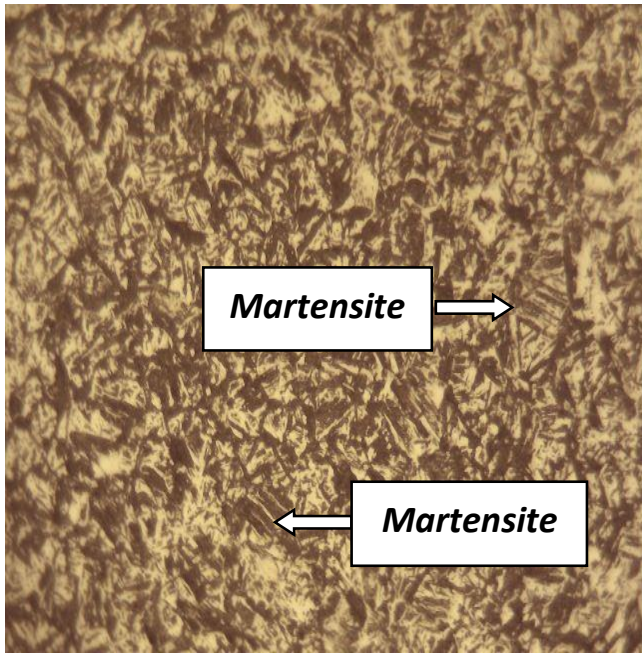

(a)

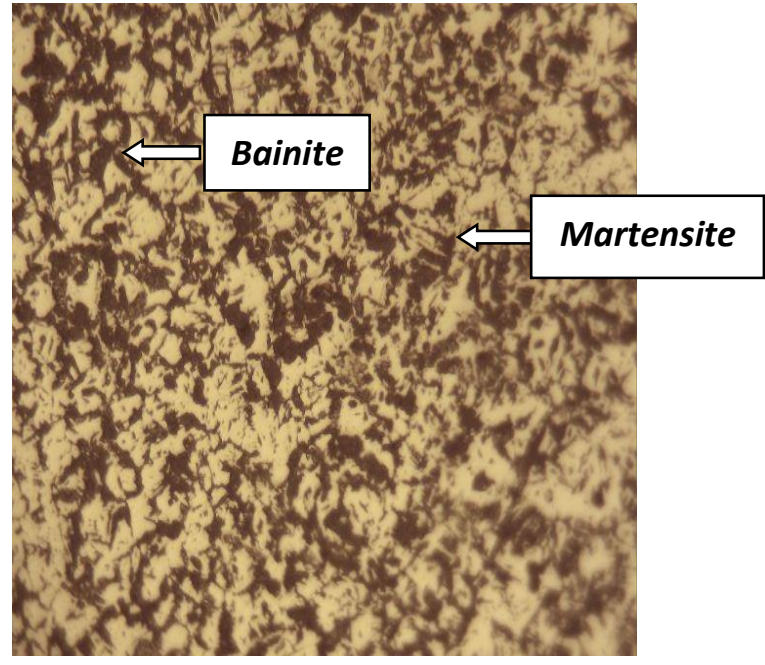

(b)

Gambar 6. (a) Struktur mikro baja AISI 1045 setelah dilakukan proses quenching pada suhu $900^{\circ} \mathrm{C}$ dengan holding time selama 25 menit menggunakan media pendingin air, pembesaran 222x, (b) Struktur mikro baja AISI 1045 setelah dilakukan proses quenching pada suhu $800^{\circ} \mathrm{C}$ dengan holding time selama 25 menit menggunakan media pendingin oli SAE 20W-50, pembesaran 222x.

Pada temperatur $850^{\circ} \mathrm{C}$ dengan media pendingin oli SAE 20W-50 struktur mikro yang terdapat pada Gambar 7(a) memiliki jumlah martensite yang cukup lumayan banyak, hal ini dipengaruhi dari nilai rata-rata kekerasan yang diperoleh sebesar $402,55 \mathrm{HV}$. Struktur mikro pada suhu $850^{\circ} \mathrm{C}$ memiliki karakteristik yang berbeda dengan suhu $800^{\circ} \mathrm{C}$, hal ini 
Gunawan Dwi Haryadi dkk /Jurnal Rekayasa Mesin p-ISSN: 1411-6863, e-ISSN: 2540-7678 Vol.16|No.1|255-264|Agustus|2021

dikarenakan pada suhu $850^{\circ} \mathrm{C}$ struktur martensite mulai terlihat dan terbentuk jelas seiring dengan naiknya nilai kekerasan baja. Selanjutnya, pada Gambar struktur mikro 7(b) memiliki jumlah martensite yang sangat banyak dibandingkan dengan gambar $8 \mathrm{~g}$ pada suhu $850^{\circ} \mathrm{C}$, hal ini dipengaruhi dari nilai rata-rata kekerasan yang diperoleh sebesar 476,92 $H V$. Pada suhu $900{ }^{\circ} \mathrm{C}$ struktur martensite sangat terlihat jelas dan sangat mendominasi area pada permukaan baja.

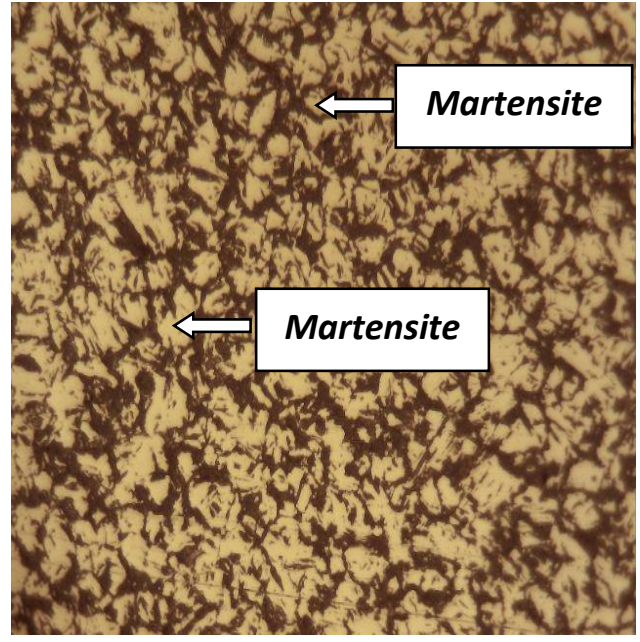

(a)

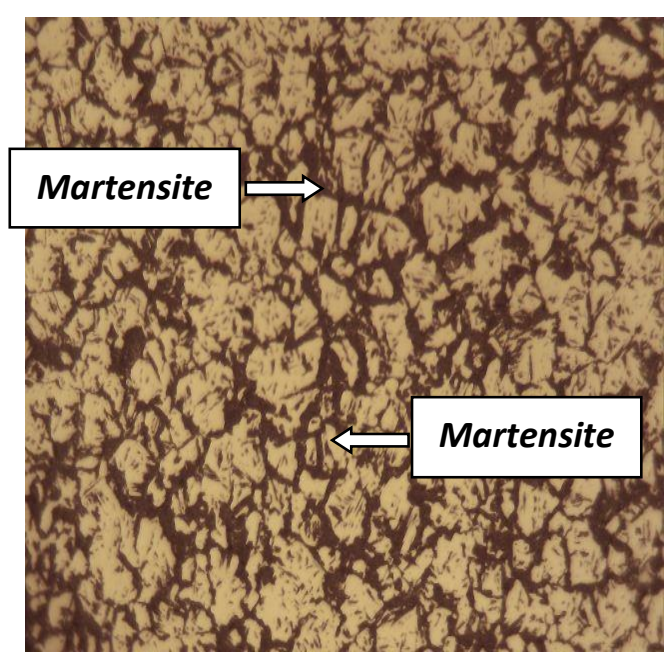

(b)

Gambar 7. (a) Struktur mikro baja AISI 1045 setelah dilakukan proses quenching pada suhu $850^{\circ} \mathrm{C}$ dengan holding time selama 25 menit menggunakan media pendingin oli SAE 20W-50, pembesaran 222x, (b) Struktur mikro baja AISI 1045 setelah dilakukan proses quenching pada suhu $900^{\circ} \mathrm{C}$ dengan holding time selama 25 menit menggunakan media pendingin oli SAE 20W-50, pembesaran 222x.

Pada proses perlakuan panas quenching, ketika baja dipanaskan hingga melewati temperatur eutectoid dan didinginkan secara cepat, maka fase austenite berubah menjadi martensite, hal ini terjadi dikarenakan difusi antar atomatom secara serentak dalam waktu yang sangat cepat, sehingga atom-atom yang tertinggal pada saat terjadi proses pergeseran atom-atom akan berada dilarutan padat ( $\alpha$ ferrite) [6]. Menurut Callister menegaskan bahwa dalam hal ini baja yang berada pada struktur martensite akan memiliki sifat keras. Unsur karbon yang terdapat pada baja merupakan elemen pengeras utama. Efek penguat utama karbon ini terdiri dari penguat larutan padat dan penguat dispersi karbida [15].

Transformasi martensite terjadi ketika pada pendinginan secara cepat dan pada suhu tinggi. Pada proses ini terdapat endapan austenite yang menyebar menjadi campuran dua fasa yaitu ferrite dan karbida yang ditekan [15]. Konsentrasi karbon martensite ini sesuai dengan kondisi austenite. Transformasi austenite menjadi martensite dimulai ketika melewati suhu awal martensite (M). Martensite terbentuk pada interval suhu tertentu yang diiringi oleh laju pendinginan secara cepat [15]. Totten menegaskan bahwa proses pendinginan dibawah Ms akan menyebabkan jumlah martensite meningkat dengan cepat karena pembentukan pelat (jarum) baru yang sangat cepat. Pelat (jarum) yang awalnya terbentuk tidak tumbuh seiring dengan waktu. Suhu Ms mendefinisikan bahwa pada temperatur tersebut tergantung pada paduan dan menurunnya suhu secara drastis seiring dengan peningkatan kandungan karbon baja [15]. Bagian dari karbon ini akan memasuki karbida yang telah menyatu dengan austenite. Karbida akan larut dalam austenite jika suhu pendinginan dinaikan, hal ini menyebabkan konsentrasi karbon austenite akan meningkat [15].

Perbedaan variasi temperatur quenching dan komposisi yang terdapat pada baja AISI 1045 akan mempengaruhi jumlah martensite yang terbentuk. Unsur karbon pada baja AISI 1045 sebagai pengeras untuk meningkatkan sifat 
mekanik. Proses perlakuan panas quenching dalam hal ini dapat meningkatkan kekerasan, serta akan mendapatkan struktur mikro bainite dan martensite. Pemilihan suhu dalam penahanan material sangat berpengaruh terhadap proses transformasi fase dari pearlite menjadi austenite. Waktu penahanan untuk klasifikasi baja karbon sedang yang baik untuk merubah fase dan mendapatkan struktur austenite yang homogen selama 15-25 menit. Untuk mekanisme waktu penahanan austenisasi bergantung pada komposisi dan konstituante mikrostruktur baja serta derajat karbida yang diinginkan [16]. Thelning menegaskan bahwa waktu penahanan sangat berpengaruh terhadap transformasi fase dan difusi karbon dengan elemen unsur lainnya yang terdapat pada baja [17]. Apabila waktu penahan terlalu cepat dan kurang tepat sesuai dengan klasifikasi baja maka akan mengakibatkan proses transformasi tidak sempurna dan tidak homogen [2-3]. Pemilihan suhu 800,850 , dan $900^{\circ} \mathrm{C}$ waktu penahanan (holding time) selama 25 menit diharapkan mendapatkan sifat mekanik terutama sifat kekerasan yang optimal pada material tersebut. Selain itu, pemilihan jenis media pendingin yang digunakan dalam penelitian ini akan mempengaruhi sifat kekerasan, dikarenakan media pendingin air dan oli SAE 20W50 memiliki viskositas, densitas, dan laju pendinginan yang berbeda-beda.

\section{Kesimpulan}

Proses perlakuan panas quenching pada baja AISI 1045 dengan beberapa variasi temperatur pemanasan dan media pendingin menunjukkan pengaruh yang cukup signifikat terhadap nilai kekerasannya. Pada media pendingin air tingkat kekerasannya lebih tinggi dibandingkan oli seri SAE 20W-50. Hal ini dapat dipengaruhi oleh tingkat viskositas, densitas, dari kedua media pendingin tersebut. Pada proses pemanasan suhu austenisasi, baja bertransformasi dari pearlite menjadi austenite. Selanjutnya, pengaruh dari media pendingin ini menyebabkan terbentuknya struktur mikro bainite dan martensite. Hasil pengamatan struktur mikro menunjukkan bahwa, pendingin air didominasi oleh struktur martensite, sedangkan pendinginan menggunakan oli SAE 20W-50 menunjukan stuktur bainite dan martensite.

\section{Daftar Pustaka}

[1] Rifai, Damhuji, Ahmed N. Abdalla, Noraznafulsima Khamsah, Mohd Aizat, and Muhd Fadzli, "Subsurface Defects Evaluation Using Eddy Current Testing”, Indian Journal of Science and Technology, 9(9), 1-7, 2016.

[2] Pramono, Agus, "Karakteristik Struktur Mikro Hasil Proses Hardening Baja AISI 1045 Media Quenching Untuk Aplikasi Sprochet Rantai”, Teknika: Jurnal Sains Dan Teknologi, 7(2), 115-124, 2011.

[3] Pramono, Agus, "Karakteristik Mekanik Proses Hardening Baja AISI 1045 Media Quenching Untuk Aplikasi Sproket Rantai”, Jurnal Ilmiah Teknik Mesin, 5(1), 32-38, 2011

[4] Fernandes, Peter, and K. Narayan Prabhu, "Effect of Section Size and Agitation on Heat Transfer during Quenching of AISI 1040 Steel”, Journal of Materials Processing Technology, 185(1), 1-5, 2007.

[5] Dowling, Norman E., "Mechanical Behavior of Materials: Engineering Methods for Deformation, Fracture and Fatigue, Fourth Edition”, Choice Reviews Online, 2012

[6] Callister, Wd, "Materials Science and Engineering": An Introduction, Jr.-7th Ed.p. Cm.,TA403.C23 2007, John Wiley \& Sons, Materials Science and Engineering, 2007

[7] Asyara, Meiriza \& Syahrul, "Efek Quenching Dengan Media Pendingin Yang Berbeda Terhadap Nilai Kekerasan Pisau Berbahan SUP 9", Journal of Multidicsiplinary Research and Development, 1(4), 887-896, 2019.

[8] Handoyo, Y., "Pengaruh Quenching Dan Tempering Pada Baja Jis Grade S45C Terhadap Sifat Mekanis Dan Struktur Mikro Crankshaft', Jurnal Ilmiah Teknik Mesin Unisma '45’ Bekasi, 3(2), 102-115, 2015. 
[9] Anggoro, Sotya, "Pengaruh Perlakuan Panas Quenching Dan Tempering Terhadap Laju Korosi Pada Baja AISI 420”, Jurnal Engine: Energi, Manufaktur, Dan Material, 1(2), 19-29, 2017.

[10] Ginting, Ediman, Endarmoko -, and Roniyus Marjunus, "Pengaruh Variasi Waktu Tahan Pada Austenisasi Dengan Pendinginan Cepat Terhadap Kekerasan Dan Ketangguhan Baja AISI 1045”, Jurnal Fisika Indonesia, 24(1), 47-51, 2020 .

[11] Rifnaldi, Randy \& Mulianti, "Pengaruh Perlakuan Panas Hardening dan Tempering Terhadap Kekerasan (Hardness) Baja AISI 1045”, Journal of Multidicsiplinary Research and Development, 1(4), 950-959, 2019.

[12] Kim, Wonsik, and Patrick Kwon, "Phase Transformation in Machining Steels", in Tribology Series, 39, 439-446, 2001.

[13] Ibrahim, Akhyar, “Efek Perlakuan Panas Terhadap Retakan Pada Bahan AISI 1045”, 8(1), 698-704, 2010.

[14] Kalpakjian, Serope, and Stephen Schmid, "Manufacturing Engineering and Technology", SI 6th Edition, Pearson, 2013

[15] Totten, George E., "Steel Heat Treatment: Metallurgy and Technologies", Steel Heat Treatment: Metallurgy and Technologies, 2006

[16] Dossett, Jon, and George Totten, “ASM Handbook, Volume 4B: Steel Heat Treating Technologies”, ASM International, 2014

[17] Thelning, Karl-Erik, "Steel and Its Heat Treatment", Bofors Handbook, Nature, 1967 